\title{
Chinese Indonesians under Jokowi: Flourishing Yet Unsettling
}

\section{Enny Ingketria ${ }^{1,2}$}

${ }^{1}$ School of Journalism and Information Communication, Huazhong University of Science and Technology, Wuhan, China ${ }^{2}$ Sub Directorate of Oil and Gas Cooperation Affairs, Ministry of Energy and Mineral Resources, Jakarta, Indonesia

Email: ingketria@hust.edu.cn

How to cite this paper: Ingketria, E. (2018) Chinese Indonesians under Jokowi: Flourishing Yet Unsettling. Open Journal of Social Sciences, 6, 94-121. https://doi.org/10.4236/jss.2018.67009

Received: June 24, 2018

Accepted: July 17, 2018

Published: July 20, 2018

Copyright $\odot 2018$ by author and Scientific Research Publishing Inc. This work is licensed under the Creative Commons Attribution International License (CC BY 4.0). http://creativecommons.org/licenses/by/4.0/

\begin{abstract}
From the Dutch colonial times until the end of Suharto era, Chinese Indonesians had gone through a series of institutional racism, as well as racial prejudice and discrimination, but Suharto's New Order period was portrayed by some scholars as the toughest situation most Chinese Indonesians had to deal with at that time. If during the reign of Suharto, they found few accesses to express their Chinese identity, after the fall of Suharto, they were given more alternatives to articulate their Chinese-ness, either through media products or cultural activities. Nonetheless, in the first six years of post-Suharto era, the political and economic conditions were not yet stable, while the residual prejudice against Chinese Indonesians and the shadow of cultural trauma remained. Since previous studies have merely focused on the negative stereotypes towards ethnic Chinese in Indonesia, this research elaborates the identity formation of Chinese Indonesians during the administration of President Joko Widodo (Jokowi), who is popularly known as pluralist figure. By using in-depth interview and participant observation to 30 participants who were mostly fourth generations of Chinese Indonesians, Chinese Indonesians today are still facing identity dilemma, in which they were predisposed to hide their ethnic identity, yet they were inclined to recover the image of Chinese identity in public. The cultural long-distance nationalism observed indicates that the younger generations of Chinese Indonesians nowadays have indeed strong emotional ties to their ancestral homeland.
\end{abstract}

\section{Keywords}

Chinese Indonesians, Cultural Long-Distance Nationalism, Ethnic Identity, Identity Dilemma

\section{Introduction}

As an archipelagic state, Indonesia is comprised of diverse ethnic groups, in 
which ethnic Chinese made up just about $1.2 \%$ of the population (Source: CIA World Factbook). Throughout Indonesia's history, Chinese Indonesians were overwhelmed by insecurities and anxiety, due to the perpetual racial prejudice, stereotype, and discrimination addressed by pribumi. Nevertheless, the toughest situation occurred during Suharto's authoritarian rule, with his implementation of forced assimilation policy, where ethnic Chinese faced severe cultural and educational restrictions. After the fall of Suharto, the rigid restrictions have been lifted and Chinese Indonesians have more accessed to Chinese culture and language. However, those previous studies that paid more attention on Chinese Indonesians' identity in post-Suharto era mostly emphasized on the residual stereotype and prejudice [1] [2] [3] [4] [5]. In addition, there has not been a more focused research on identity of Chinese Indonesians under the incumbent President of Indonesia, Joko Widodo (Jokowi).

Chinese Indonesians has entered a "real" democratic phase in the first two years under the $7^{\text {th }}$ President of Indonesia, Joko Widodo, for he is popularly known as a leader with ideas of respectful toleration and pluralism. Under his rule, an Indonesian of Chinese Descent, Basuki Tjahaja Purnama (Ahok), served as the Governor of Jakarta November 2014-May 2017. Ahok does not only represent a new milestone for inclusiveness, he is known for his main priorities that include good governance, better welfare, programs of health care, and education. Aside from his good performance, Ahok is recognized for being brash and blunt, different from the soft-spoken Javanese politicians the capital is used to. This led him to the blasphemy allegations in September 2016. He found guilty and faced a two-year imprisonment in 2017. Ahok's blasphemy case has undermined the first two years of Chinese Indonesians' confidence and their positive image as well. Ahok's imprisonment has become the highest point of tension during Jokowi's administration, therefore how those Chinese Indonesians cope with the process and how their identity maintained will be further discussed in this study.

This paper will describe the research methods, followed by Jokowi's positive image of being the popular and people-centric leader. In addition, this study also emphasize that under Jokowi, Indonesia forges stronger ties with China, while a number of Chinese Indonesians who hold leadership positions in the government act as the bridge between Indonesia and Mainland China. However, this favorable external condition under President Jokowi was abruptly undermined due to the accusation of blasphemy against Ahok. What should also be taken into account is the digital media boom under Jokowi that has significant impact for establishing good image of both President Jokowi and Chinese Indonesians themselves. Therefore, this study is trying to find out how younger generations of Chinese Indonesians today maintain their ethnic identity under such condition. In order to confirm the results of the interview and observation, two second-generations of Chinese Indonesians were also interviewed and observed. The findings will be elaborated in Chapter 9 . 


\section{Methods}

According to Phinney [6], both conceptual and empirical writings acknowledge that ethnic identity is a dynamic construct that changes over time and context and varies across individuals. Adolescents and young adults are assumed to progress over time from an unexamined or received view of their ethnicity-based on attitudes of parents, communities, or society-through a crisis or exploration phase, in which they immerse themselves in the history and culture of their group, to an achieved, secure sense of their ethnicity.

This study analyzed the identity formation of Chinese Indonesians during Jokowi era using qualitative method; in-depth interview and participant observation. In order to obtain rich and descriptive data about the participants' identity formation, in-depth interview has to be conducted, combined with participant observation that is aimed at gaining a close and intimate familiarity with the respondents. As the first step, links to screening questionnaire were shared through social media and e-mail. As the screening questionnaire indicates, the items were presented in a qualification format and the questionnaire was designed in such a way. Those who were self identified as Chinese Indonesians, resided either in Jakarta, Tangerang, or Bandung, and with ages range from 20 30 , were selected to be part of in-depth interview and participant observation process. The selection is also based on their answers regarding their fluency in Chinese language and their political attitudes. There were 30 participants who were shortlisted and willing to follow the whole process of survey.

\section{Joko Widodo's Popular Image as the 2014 Indonesian Presidential Candidate}

The Indonesian legislative elections were held on April 9, 2014 and took place in 33 provinces [7]. There were three secular parties that received high percentages of votes, based on the quick counts by polling agencies; the opposition Indonesian Democratic Party-Struggle (PDI-P), Party of the Functional Groups (Golkar), and Great Indonesia Movement Party (Gerindra) [8]. Joko Widodo, popularly known as Jokowi, was at that time the PDIP-P presidential candidate and the incumbent governor of Indonesian capital city, Jakarta, as well. He was expected to be the next Indonesian president who would improve the particularly economic and social conditions in Indonesia. As emphasized by Bland [8], the 6th President of Indonesia, Susilo Bambang Yudhoyono (SBY), failed to live up to expectations that he would fight corruption and fix the nation's ailing infrastructure, in spite of the fact that his administration was much better compared to his predecessors; B.J. Habibie, Abdurrahman Wahid, and Megawati Sukarnoputri. He led Indonesia to a more peaceful and democratic phase.

As a figure of hope, Jokowi came in the right place at the right time. In addition, his image had been successfully established by the media since he became the successful mayor of Surakarta, a city in Central Java, Indonesia, from 2005 until 2012. Jokowi was then nominated by $P D I-P$ as their candidate for the 2012 
Jakarta gubernatorial election, alongside with Basuki Tjahaja Purnama (Ahok) who was nominated by Gerindra as the potential running mate candidate for Jokowi. In October 2012, Jokowi was then elected and officially appointed as the Governor of Jakarta. He rose to national prominence because of his continuous improvement of bureaucratic systems and publicized blusukan visits (unannounced spot checks). Since he is seen as a populist politician who had been more pluralist in his outlook, in the 2014 presidential election, $P D I-P$ nominated Jokowi as their presidential candidate. Even Kevin O'Rourke, the principal of PT. Reformasi Info Sastra, as quoted by Emont [9], regarded Jokowi as phenomenal leader with the "Jokowi Effect" aura.

Jokowi came out with his unconventional outlook, bottom-up approach, and people-oriented approach. His unconventional leadership and management style have made him a popular figure nationwide, for he grabbed the national media's attention [10].

\section{Jokowi as the $7^{\text {th }}$ President of Indonesia-The Man of the People}

After defeating chairman of the Great Indonesia Movement Party (Partai Gerakan Indonesia Raya (Gerindra)), Prabowo Subianto, in the July 2014 presidential election, Jokowi was officially elected the $7^{\text {th }}$ Indonesia's President in October 2014. Through his political support base, Jokowi's pluralism and religious tolerance were demonstrated. He was supported by secular pluralist parties, such as $P D I-P$, and the National Democratic Party, and pluralistic Islamic scholars. Furthermore, another Islamic political party that promotes inclusive and nationalist principles, National Awakening Party, also announced its support for Jokowi. In order to protect religious communities, Jokowi's newly appointed Minister for Religious Affairs, Lukman Hakim Saifudin, declared plans for new laws [11].

Looking back at how he governed Solo (Surakarta), Jokowi had been successful in managing the problems of the majority of the residents. Emont [9] argued that Solo was plagued by congestion, in part because street traders crowded in city centre had refused to move. Jokowi came up with good and innovative solutions to the problems faced by residents in Solo, wherein he developed an alternative covered market for the locals, established universal healthcare for residents, transformed the city into a tourist destination, and improved the inefficient bureaucracy. His "out of the box" image exposed by the media has made him "the most appropriate figure" for the majority of Jakartans to be the governor of Jakarta. After officially being elected as the Governor of Jakarta, together with Ahok as his deputy Governor, he proved those sceptics wrong about his inability to lead Jakarta with his blusukan style of politics. In spite of the fact that he had only been in office for only a year and a half, Jokowi had proven to be a great leader, wherein he solved problem of floods in Jakarta and developed public transport for Jakarta, the MRT (Mass Rapid Transit). As the next "Indonesian 
Obama", the majority of Indonesians, hang their hope on Jokowi to lead Indonesia out of its comfort zone.

After being elected as Indonesia's $7^{\text {th }}$ President in 2014, Jokowi urged for a spirit of unity and hard work, and promised to restore national pride as well as build a stronger maritime presence. As argued by Emont [12], Jokowi entered office in the midst of social and economic problems. Communicating with the public had been Jokowi's main concern during his first year in office. As a figure who kept up with the times, he made use of one of the popular video sharing website to communicate virtually with his people his recent concerns and programs. In addition, in order to attract foreign investment and ease of doing business in Indonesia, Jokowi had also released 12 economic reform packages.

According to Panjaitan [13], in order to fulfil his government's goals, Jokowi called for greater unity within his cabinet, including cutting bureaucratic red-tape, accelerating infrastructure development, and reducing income inequality. He also asked his ministers to adhere to one agenda and one vision. In addition, Jokowi stated in the first years of his rule that his main focus was also to welcome foreign investment and increase strategic partnership with a number of influential countries, including China, by introducing thirteen economic policy packages supporting investments [14]. A series of reforms have generated waves of optimism that Indonesia is eager to integrate with the global economy. Foreign investors responded favourably to the economic reforms and saw an increase in foreign investment in 2015 by 19.2 per cent.

\section{Indonesia-China Commitment-Forging a Strategic Partnership}

During Jokowi's first official trip as Indonesia's President, Chinese President Xi Jinping hailed Indonesia as being "close to the heart" of China.

We have a proverb that says: "out of sight, close to the heart". Although our two nations are separated by a vast ocean, the huge waves have not deterred us from interacting since the era of Admiral Cheng Ho's voyage (in the $15^{\text {th }}$ century) and the Asia-Africa Conference in 1955. The two countries have developed a deep friendship, with mutual respect, as neighbours and old friends. (Xi Jinping, 2014)

President Xi emphasized the historical relations between Indonesia and China which could be traced back to the era of Cheng Ho's voyage. He then added he believed the Chinese-Indonesian "comprehensive, strategic partnership" signed in 2013 by him and SBY would continue to develop. In response to President Xi's statement, Jokowi signalled that his approach to Sino-Indonesian relations would be much concrete than that of his predecessor, SBY. During his first encounter with President Xi on November $9^{\text {th }} 2014$, Jokowi bluntly stated that he wanted the relationship to "materialize into more concrete outcomes" [15]. In September 4-5, 2016, in Hangzhou, China, Jokowi took the opportunity while attending the $11^{\text {th }}$ G20 Summit to meet again with President Xi. Both countries 
were seeking to further develop their economic relations, as well as leverage their geographical location and maritime prowess [16]. In addition, in order to enhance the bilateral cooperation in energy sector, Ignasius Jonan, the Minister of Energy and Mineral Resources, signed an agreement with China on the sidelines of the fifth Indonesia-China Energy Forum (ICEF V) in November 2017 in Jakarta [17].

During the $3^{\text {rd }}$ Meeting of the Joint Commission on Bilateral Cooperation Between China and Indonesia held in February $9^{\text {th }} 2018$ in Beijing, Wang Yi, Chinese Foreign Minister, stated that China is going to promote cooperation with Indonesia under the Belt and Road Initiative. Furthermore, Wang announced China's willingness to advance cooperation in other strategic sectors under different frameworks

\section{Chinese Indonesians-Bridging the Gap}

As mentioned before, during the SBY era (2004-2014), the discrimination and racial prejudice against Chinese Indonesians, has considerably been diminished. Instead, through the celebration of cultural festival, Chinese rituals, and traditions, they felt a sense of cultural pride within their heart. Moreover, the China's rise to global economic superpower recently has provoked their long-distance nationalism, expressed through any cultural activities held in public. Setijadi [18] stated that many Chinese Indonesians recently held Chinese culture and oriented themselves towards Mainland China in the post-Suharto era. Furthermore, most of them felt a stronger sense of belonging to China than at the time when forced assimilation was implemented during the rule of Suharto, especially the older totok Chinese Indonesians (pre-1965 generation), who experienced the "erasure" of Chinese identity and culture during the New Order. For these ethnic Chinese, and for the subsequent generations as well, the rise of China as global power rouses a sense of ethnic pride and legitimation.

Setijadi added that over the last two decades, a sharp rise has been observed in the uptake of Mandarin language learning among the worldwide ethnic Chinese population [3]. In addition, China has become one of the top destinations for higher education for international students. Especially for Chinese Indonesians, their main motivation for learning Chinese language and acting as intermediaries between Indonesia and China is to keep up and ride on the wave of China's rise.

There are currently two ethnic Chinese influential figures who were appointed by Jokowi important strategic positions in Indonesia's government. In November 2017, the Ministry of Energy and Mineral Resources of Chinese Descent, Ignasius Jonan, signed an agreement with China to strengthen cooperation in the energy sector on the sidelines of the fifth Indonesia-China Energy Forum (ICEF V). Apart from signing an agreement, both countries also established two working groups on oil, gas, and coal as well as on renewable energy for electricity. Here, CNOOC, Petrochina, and SINOPEC, are among Chinese companies that 
have started investing in oil and gas in Indonesia.

Another important decision maker in the government is Thomas Lembong, the chairman of Investment Coordinating Board (BKPM). Thomas Lembong, a 44-year-old ethnic Chinese, affirmed that in a limited number of regions, Indonesia would offer infrastructure projects. Indonesian Chamber of Commerce and Industry deputy chairperson of international relations, Shinta Widjaja Kamadani, stated that Indonesia has a number of projects that are in line with OBOR (One Belt One Road) program; toll roads, sea ports, airports, and power plant projects.

Those ethnic Chinese who are currently have strategic positions in Indonesia's government play significant roles in bridging the gap between Indonesia and Mainland China. In addition, since ethnic Chinese and native Indonesians have been able to exist in Indonesia, and the situation has been much more conducive until September 2016, becoming both the "cultural and commercial bridging role" is not a problem for a number of Chinese Indonesians who are working for the government [3]. However, Setijadi [18] argued that apart from all developments, there are worries about potential backlash to "overt" public displays of Chinese culture, the use of Mandarin, and closeness to China. Such uncertainty indicates the presence of negative ideological connotations about China and Chinese Indonesians' loyalty in post-Suharto Indonesia.

Setijadi's statement might be true to some extent, but based on the researcher's in-depth interview and participant observation, after the appointment of Jokowi, the pluralist politician, through the peaceful celebration of Chinese New Year, the co-existence between pribumi and Chinese Indonesians can be observed. In addition, following the revival of Chinese culture after a period of repression, Chinese Indonesians were inclined to express publicly their Chinese identity so as to eliminate any racial prejudice addressed to them in the future. Moreover, the strong bilateral cooperation between Indonesia and Mainland China has been broadcasted nationally and internationally by any media. It has not elicited a tension between pribumi and Chinese Indonesians, until Ahok, the former ethnic Chinese Governor of Jakarta, on the campaign trail in September 2016, referenced a verse from the Islamic holy book. In addition, the Chinese-Javanese cultural harmony is represented through the Chinese New Year celebration in Surakarta, Central Java.

\section{Ahok's Two Years of Imprisonment-Post-Suharto Racial Tension}

After President Jokowi was officially appointed as the $7^{\text {th }}$ President of Indonesia, Basuki Tjahaja Purnama, better known as Ahok, was then elected as the Governor of Jakarta. Under his rule, Ahok did improve a lot of problems in Jakarta, including physical and bureaucratic transformations. He had publicly vowed to turn the nation's capital into an orderly city rivalling Singapore [19]. Yet he was criticized for his two character traits most Indonesians didn't expect from an 
Indonesian politician-outspoken and brash.

According to Tanaya [20], Ahok continued applying system of e-budgeting for the city's budget introduced by Jokowi. He launched an application that allowed citizens to make reports to the public service, which was able to reduce red tape. In addition, Ahok's no-nonsense approach has brought many changes to Jakarta, such as solving flood problem. It's argued that Ahok is a reform figure whom most Jakartans hang their hope on. He is also a symbol of confidence and dignity for younger generations of Chinese Indonesians, wherein as an ethnic Chinese, Ahok could make Jakarta a better place to live in.

Even though there were critics regretted Ahok's fiery character when he responded to reporters and his constituents, Ahok had been continuously supported by most Jakartans for his outstanding performance. Furthermore, the political situation in Jakarta at that time had been relatively stable. The most striking moment happened when Ahok referenced a verse from Islamic holy book, Al-Maidah 51 of the Qur'an, on the campaign trail in September 2016, where he told voters to avoid getting duped by religious leaders who claimed that moslem should not be led by non-moslem. His speech was later posted online and circulated nationally. Ahok's speech had provoked anger among moslem, including the Islamic Defenders Front (FPI) and other hard-line moslem groups, after his video reached a large number of viewers. A poll by Saiful Munjani Research Consulting (SMRC) showed that more than $45 \%$ of Indonesians had no doubt that Ahok's statement was blasphemous [21].

In response to Ahok's statement regarding the qur'anic verse, the conservative Moslem groups led three massive protests that paralyzed downtown Jakarta, demanding the governor be jailed because of the comments he made during political campaign for the gubernatorial election in 2017. Ahok apologised after the incident, but it didn't appease the hardline moslem groups to demand that Ahok be prosecuted for blasphemy. Ahok blasphemy case was a decisive factor in his defeat to a Moslem candidate in the 2017's gubernatorial election. After a trial that was widely seen as a measure of religious pluralism in Indonesia, Ahok was then sentenced to two years in prison [21].

What has been taken into account was not actually the accusation made against Ahok for his inappropriate speech, but Ahok as an ethnic Chinese. As a minority who has been jailed because of blasphemy, Ahok's case has become big question mark for most Chinese Indonesians. After going through a great depression under Suharto, and in the end a freedom of cultural expression for more than a decade and a half, particularly under SBY and Jokowi's two-yearperiod, Chinese Indonesians experienced a mental disharmony. A number of native Indonesians once again associated Chinese Indonesians as "disloyal minority who controls the Indonesia's strategic sectors". It is with no doubt the case of Ahok brought a new type of racial tension during the Jokowi's democratic regime.

The turmoil did activate anti-Chinese sentiments in Indonesia. The long his- 
tory of persecution had caused a state of anxiety among Chinese communities. According to Chung-Yan [22], Chinese Indonesians had perpetually been eyed with suspicion by local people, regardless of the fact that their forefathers were among the first settlers of the archipelago who built the modern city of Jakarta. To discover how those younger generations of Chinese Indonesians who were born between 1990 to 1998 maintain their identity, the author had interviewed 30 third-fourth generations of ethnic Chinese. Prior to the in-depth interview, the author administered a screening questionnaire that was aimed at ensuring that the participants met the criteria established by the author. Only those who were self-identified as Chinese Indonesians, exposed to Chinese new media, fluent in Chinese language, and had some political standpoints, were selected to be further interviewed and observed. In addition, the author also did in-depth interview to two important figures of Chinese descent; Jusuf Hamka, a philantropeneur, and Tamin Suliman, a medical doctor, so as to obtain a more comprehensive understanding upon the current condition faced by Chinese Indonesians today.

\section{The Digital Media Boom under Jokowi}

According to Rakhmat [23], Indonesia is one of the top social media markets in the world, although only a quarter of its population have Internet access at home. With regards to the number of Internet users, a recent report entitled "Digital in 2017 Growth Overview" states that Indonesia nowadays is the fastest-growing country compared to 2016. The country is nearly three times above the global average, with 51 per cent growth annually. In addition, Indonesia also comes fourth in the highest number of Facebook users, after Brazil, India, and the United States. The most important factor that causes the popularity of social media among Indonesians is the accessibility of mobile Internet devices-mostly smartphones, which have doubled in usage over the recent yearscoupled with affordable data plans. Any content available on the Internet is freely accessed, retrieved, and shared as well. Another report mentioned that Indonesia boasts the third-highest growth in mobile social media use worldwide.

Based on Figure 1, Facebook is the most favourite social media used among Indonesians, followed by WhatsApp and Twitter. Even today, the users of Instagram, a photo and video-sharing social networking service owned by Facebook, has increased. Live videos and photos flooded major social media platforms, in which the majority of the users are youth. Since social media recently has made use of mobile phone to turn effective communication into interactive and practical dialogue, those media as soft power may influence the public's opinions and views about issues and subjects. Especially today where the racial tension and conflict after Ahok's imprisonment are present, the spread of positive vibes across a number of online media platforms is essential so as to give different perspectives. As stated by Joseph Nye [25], instead of applying thorough coercion, the use of attraction to achieve one's goal is much more popular and effective today. 
INDONESIA'S MOST POPULAR SOCIAL PLATFORMS

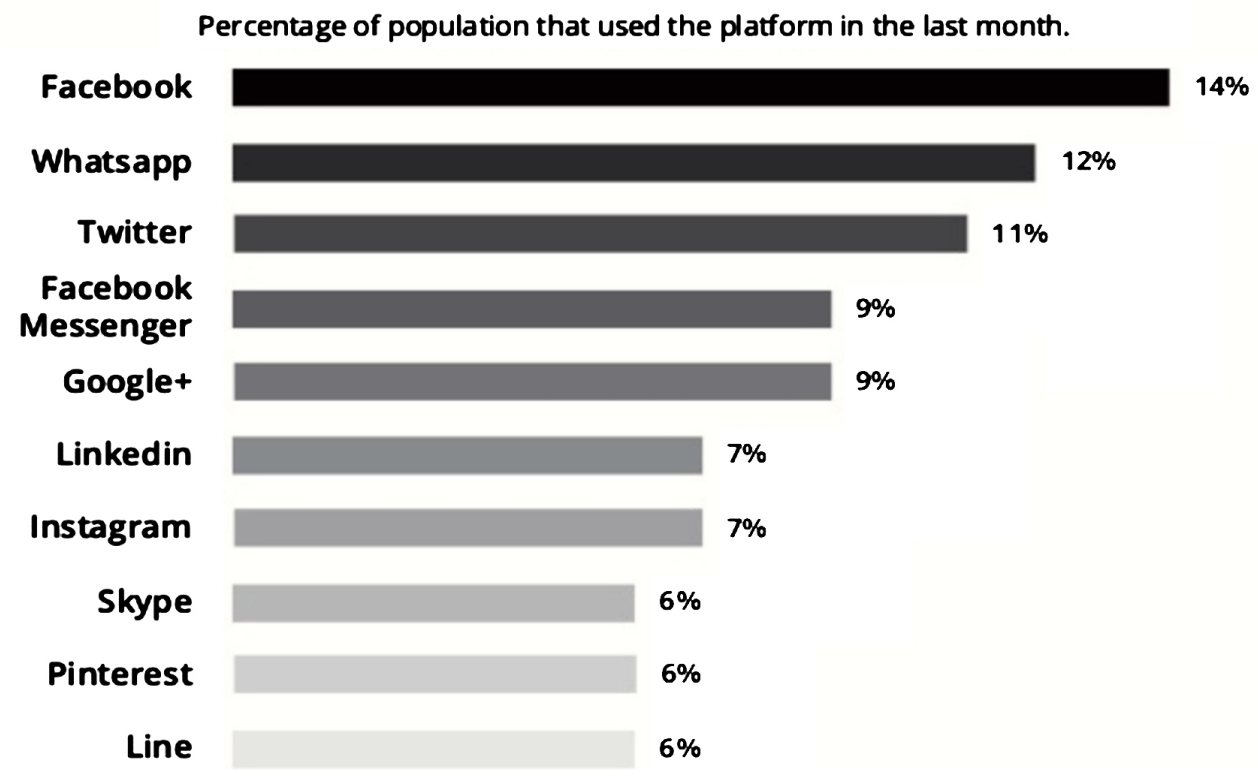

Figure 1. Indonesia's most popular platforms 2015 [24]

Social media, such as Facebook, Twitter, Youtube, and Instagram, has recently become a form of popular diplomacy, which can directly reach people and disseminate messages or opinions without depending on media organizations. This is precisely what has been done by Jokowi, who makes use of Facebook, Twitter, Youtube, and Instagram to deliver his messages to Indonesians and other people around the world. As a popular President who follows the latest trend, he also sends messages through a video blog in his personal Youtube account. As a "man of the people", Jokowi frequently shares his blusukan visits, activities, and routines as President. He gets close to his audiences by making use of the popular online platforms today. Moreover, Jokowi also becomes the role model for the majority of Indonesian populations; even a President has his own video blog ( $v \log$ ) and is humble about his stature as President. Figure 2 shows Jokowi's Social Media Flatform (Instagram) which has 9.3 million followers on Instagram.

In addition, Australian Prime Minister, Malcolm Turnbull, praises Indonesian President Jokowi as a role model for the world of preserving the spirit of diversity, during the Indonesia-Australia Youth Interfaith Dialogue and Australian Moslem Youth program, held on sidelines of the ASEAN-Australia Special Summit 2018.

Indonesia supports democracy, Islam, and moderate spirit. Standing next to me, one of the most important leaders and world role models today, I am very honoured to meet you. President Joko Widodo has successfully built multiculturalism, and this is also what Australia does. We are united by political values, democratic freedoms, and mutual respect. (PM Turnbull, 2018, as quoted by industry.co.id) 


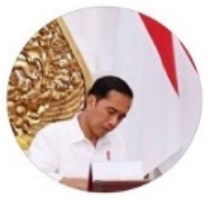

526

Joko Widodo *

Followed by nurlehty, friamygentini, annisamachinda +22 more

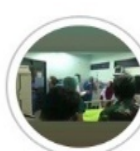

Teror Surab... Imam Al-Az...

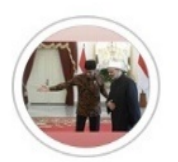

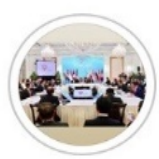

KTT Asean

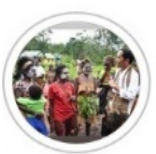

Papua

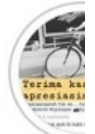

Suara I<smiles>C1#C[Si]1</smiles>

(4)
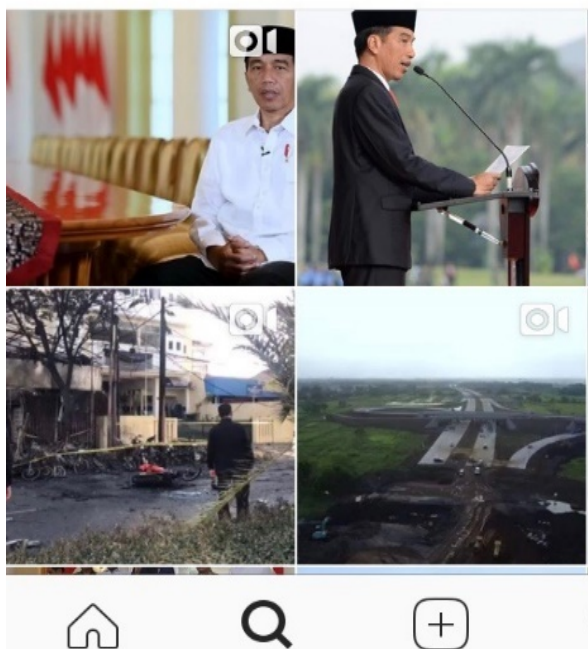

$+$
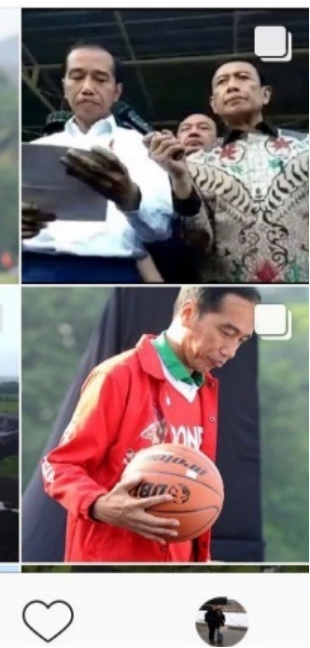

Figure 2. Jokowi's social media platform, Instagram.

\section{Findings}

\subsection{Participants-Self Effacement}

To find out if the post imprisonment of Ahok has an impact on the identity negotiation of the younger generations of Chinese Indonesians, links to screening questionnaire were shared through both social media and e-mail. There were only 30 participants who were selected to be further interviewed and observed, based on their self-identification as Chinese Indonesians, exposure to Chinese new media, fluency in Chinese language, and some political standpoints. Meanwhile researcher also conducted an in-depth interview with two public figures who are the second generations of Chinese Indonesians born in 1950s for a better understanding on how actually Ahok's case has affected the identity formation of Chinese Indonesians. Below are details of the participants in Table 1.

Based on the interview held in February-March 2018, most of the participants knew very well their Chinese names. Those who live in Tangerang and Jakarta are also born in those cities and still could explain where their ancestors came from and how long their families have lived in Indonesia. Meanwhile, the 
Table 1. Participants details.

\begin{tabular}{|c|c|c|c|c|c|c|c|c|c|c|}
\hline \multirow{2}{*}{ No } & \multirow{2}{*}{$\begin{array}{l}\text { Participants } \\
\text { Place of } \\
\text { Residence }\end{array}$} & \multirow{2}{*}{$\begin{array}{l}\text { Number of } \\
\text { Participants }\end{array}$} & \multicolumn{6}{|c|}{ Place of Birth } & \multicolumn{2}{|c|}{ Place of Ancestral Origin } \\
\hline & & & Jakarta & West Borneo & North Sumatera & Banten & West Java & East Java & Guangdong & Unknown \\
\hline 1. & Tangerang & 8 & - & - & - & 8 & - & - & 8 & - \\
\hline 2. & Jakarta & 15 & 15 & - & - & - & - & - & 15 & - \\
\hline 3. & Bandung & 7 & 1 & 2 & 1 & 1 & 1 & 1 & 7 & - \\
\hline
\end{tabular}

place of birth of those who were born in Bandung are varied, and they were able to recall when their ancestors first occupied Indonesia. The majority of those third and fourth generations of Chinese descent stated that they were born and raised in Indonesia, therefore they were inclined to identify themselves as Indonesians. They related themselves to China based on their ancestral homeland and blood, but more than that, they didn't know much about China and Chinese culture.

My parents told me that my ancestors came from Guangdong, but I was born here in Jakarta, mingled with mostly pribumi friends. I may look like a Chinese woman, but I didn't speak Chinese and haven't been to China before. Yes, we celebrate Chinese New Year every year with all its rituals and traditions, but once again, it is nothing more than respecting the cultural traditions. (Interviewee\# 1)

The majority of interviewees have the same arguments in relation with questions about China and Chinese culture. They were reluctant to respond to any questions regarding their ethnic identity. They were inclined to keep their identity low-key and were more interested to answer any questions related to their current activities and hobbies. They stated that they preferred to watch Korean and western movies, instead of watching Chinese films or TV drama series.

Surprisingly, based on the results of the participants' answers to screening questionnaire, some of them stated explicitly they were proficient at speaking Chinese as secondary language, and writing Chinese characters as well. Moreover, a number of them wrote down their favourite Chinese movies in Chinese characters. Meanwhile the other respondents demonstrated their ability to speak Chinese language, but forgot how to write down Chinese characters previously well known to them. However, they were still able to recall a large number of movies they found most appealing and entertaining. In addition, $95 \%$ of the participants still regarded Ahok as a hard working former Governor of Jakarta who had succeeded in solving the main problems faced by most residents in Jakarta. Ahok is considered an innovative and visionary leader Jakarta once had. Nevertheless, they admitted Ahok's inability to conquer his weakness; as being too forceful, crude, and arrogant. His style of leadership and governance cannot be accepted by the majority of native Indonesians with different cultural values. An ego-based leader is regarded as inappropriate figure by most Indonesians. They still uphold cultural principle, known as equanimity, and view religions as their 
important values and ways of life. Most respondents were aware that patience is a virtue in all cases, while Ahok were instead short-tempered. It is commonly known that in Indonesian culture, the fact that a person is not okay with a situation is spoken by his/her calm refusal.

The participants' statement that Ahok's brash manner is indeed controversial, shows their cultural awareness, in which Ahok's straight-talking attitude stands in stark contrast to the typically unconfrontational approach of most of Jakarta's previous leaders. He had offended the Javanese basic courteous manners. In this sense, the majority of respondents respect the mainstream culture of Indonesians that Ahok had ignored, regardless of his good reputation for clean governance. They position themselves somewhere in the middle; they supported neither Ahok nor the hardline Moslem groups. Their attitude of not explicitly and totally defending Ahok represents the self-effacement, in which they were inclined to save their position as ethnic Chinese.

\subsection{Ethnic Identity Covering}

As mentioned before, an in-depth interview was also conducted to obtain more comprehensive results. There are two persons of Chinese Descent with different background who were interviewed. The first person is Jusuf Hamka, an ethnic Chinese Philanthropreneur who was born in late 1950s, and converted to Islam in 1981. As a purposeful and determined person, he stated that he has remained resolute in his opposition to Ahok's blasphemy. To his opinion, Ahok has to be condemned for he did not respect the basic cultural sensitivities of his motherland, Indonesia. With respect to Ahok's case, he argued that Ahok had irritated the very fundamental part of Islamic religion for Indonesia is a home to the largest Moslem population in the world. Moreover, Jusuf added that Ahok's mental and moral qualities have nothing to do with Chinese culture and universal values. To his understanding, the cultural principle, known as equanimity, has its origin from the Eastern religious practices like Buddhism and Confucianism. For him, both Indonesians and Chinese have similar historical culture and values. Confucius also taught us to show love, respect, and support, as well as display courtesy to everyone in any circumstances. Therefore, to his understanding, the problem is Ahok as a minority has insulted the central religious text of Islam, which Moslems believe to be a revelation from God.

Another person who has been interviewed is a medical doctor of Chinese Descent, Tamin Suliman. As a second generation of Chinese Indonesians who were born and raised in Jakarta, Tamin knew very well the cultural values passed down by their parents who were migrants from Guangdong. He respects Chinese culture and applies the values and norms in his life, but his heart lies in Indonesia.

I guess you have heard about filial piety? It teaches us to engage in good conduct not just to parents, but also to everyone outside the home. It's not difficult for me to adjust myself to my fellow pribumis' cultural values, for we have simi- 
lar basic manners in life; to set up a good society using a virtue of respect for anyone anywhere. (Interviewee \# 2 )

Tamin added that Ahok's shortcomings do not represent the traditional Chinese cultural values his parents have taught. The ideal society according to Chinese values is "a world for all and a world of universal harmony". In his views, Ahok failed to create harmony within society. He emphasized the principle of courtesy that Ahok lacked, that is to respect the mainstream culture and prevent misconduct. As a Christian, Tamin stated that his religion taught him the same way to behave. Nevertheless, he admitted that Ahok was one of a kind. He has overcome the main problems of Jakarta and found the best solution to reform the bureaucracy.

Both Jusuf and Tamin frequently stated that as an ethnic Chinese who were born in Indonesia, they had no choice but to assimilate to the Indonesian culture. They used to mingle with their pribumi fellows, and they even thought that the forced assimilation applied by the New Order was the best way the government could do at that time to unite different races and ethnicities. They expressed complete disapproval of Ahok's violating Indonesia's archaic blasphemy laws.

You and I live in Indonesia. No matter what ethnic we are, the fact is we live here. This is our motherland and we have to respect Indonesia's basic customs, norms, and cultural principle. There is only one word for every people of Chinese descent who want to live in Indonesia: assimilation. That's is it. I am myself happy to assimilate. (Interviewee\# 3).

As a Philantopreneur, Jusuf Hamka has gained public attention recently due to his charity, wherein he had made two food stalls called Podjok Halal in late 2017, while the other three are being built. Jusuf stated that the purpose of building those food stalls is to reduce the burden of poor and low-income people. They could eat anything they like during lunch time and only have to pay three thousand Rupiah. Even for those who cannot afford to pay, Jusuf will be very happy to treat them. Meanwhile, Tamin, as a doctor, has spent years serving his patients in his neighbourhood. He will charge those who are in need or do not have insurance lower cost. Both of them with different background and religion have the same perspective and passion in relation with charity.

However, based on the researcher's participant observation, Jusuf as a business man, has also built a supermarket for a commercial purpose, in which he imported a number of products from Mainland China. He confirmed that he has a partnership with China and for him as long as the products are halal (permissible in Islamic law), there is nothing wrong to cooperate with China in various fields. He added that he is currently financing the building of a mosque in North Jakarta that has Chinese architecture style. During his visit in Beijing last year, he had the chance to pray at a beautiful mosque and he promised to himself that he would build the similar one in Indonesia. Currently the construction of the said mosque nearly finished (see Figure 3). 


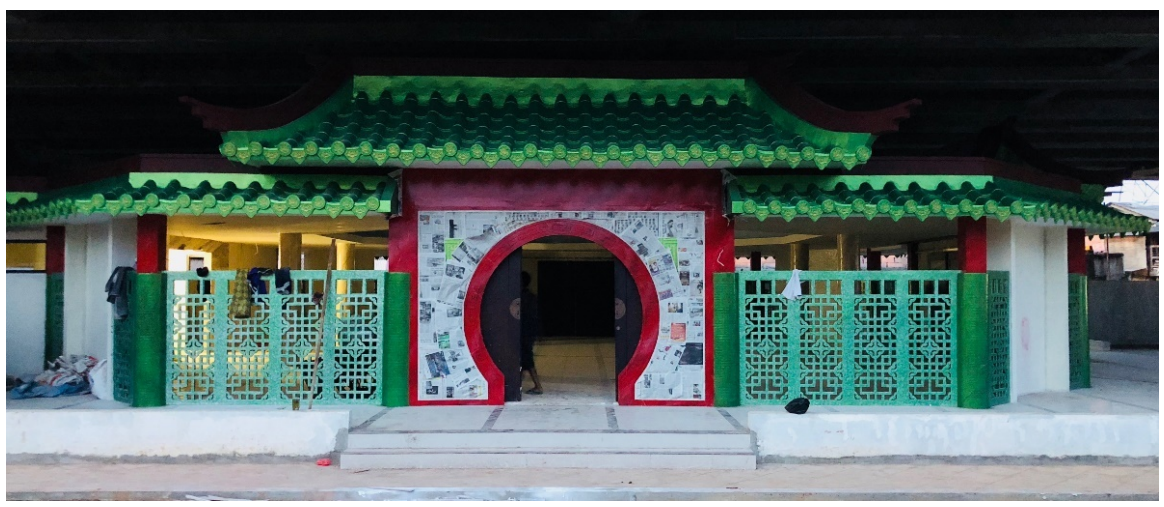

Source: Authors capture.

Figure 3. A mosque with Chinese architecture built by Jusuf Hamka.

Different from Jusuf, Tamin several times mentioned the concept of filial piety as his ways of life, where respecting elders are the crucial values most people are currently lacking of. Furthermore, his son, Tomy, stated that every year he celebrate Chinese New Year as a moment to reunite with his extended family and remember the customs and traditions of Chinese his father has delivered. They ought to dress in red and prepare red envelopes that contain money, for red is regarded as the symbol of energy, happiness, and good luck.

Even though both Jusuf and Hamka mentioned assimilation as the only solution and choice those ethnic Chinese has to choose, they, to some extent, silently protect and preserve their Chinese identity. They, once again, keep it low-key for Ahok's case has undeniably damaged the good image of Chinese Indonesians and Chinese culture. While covering their ethnic identity, they are trying to improve their positive self-image as a good Chinese. In this sense, the assimilation is used as a "cover" for the ethnic identity lies within their heart.

\subsection{New Media-Going Viral}

Indonesia has a population close to 260 million people and is considered as the fastest growing country for Internet use. While one third of Indonesians are actively using Internet, there are still a lot of connected people-88 million (source: We Are Social). While Youtube is mainly used to share vlog (video blog), social media, such as Facebook, Twitter, and Instagram are used as part of sophisticated e-commerce strategies for small business. Both Instagram and Facebook have their own vlog-like, in which the contents will be able to be posted publicly for only 24 hours.

Since more than 80 million people in Indonesia use social media, "going viral" is the newest option to share the latest video content through the social media outlets available in order to massively increase the reach of the content. If Jokowi has its own vlog to disseminate his message online, Jusuf Hamka gets online news coverage, in which a number of Indonesia's top online news journalists were invited to cover his charitable activities. His charity has higher rates of media coverage after his activities in the form of vlog has been broadcasted online 
through a number of Indonesia's recently popular social media; Facebook, WhatsApp, and Instagram. He gained public attention as businessman of Chinese descent in Indonesia who wants to be useful and help contribute to society. Figure 4 below presents Kompas TV's coverage of Jusuf Hamka.

Recently Jusuf Hamka's charity has gone viral. However, the main message is not only his activities, but also his identity as an ethnic Chinese. He stresses his faithfulness and service to Indonesia, as a place he considered as his "homeland". In this case, Jusuf is trying to restore the positive image and quality of Chinese Indonesians which has been spoiled by Ahok. The following Figure 5 is one of the headline news that straightforwardly conveys the ethnic identity of Jusuf Hamka.

It might be the only one Jusuf Hamka who are generous, but his generosity has become a popular, trending topic when it is circulated rapidly and widely from one Internet user to other users and the content attracted great attention.

\subsection{Fluctuations in Identity}

For almost three decades, Indonesia has been through three different regimes (New Order (before 1998), the reform regime (1998-2004), and democratic

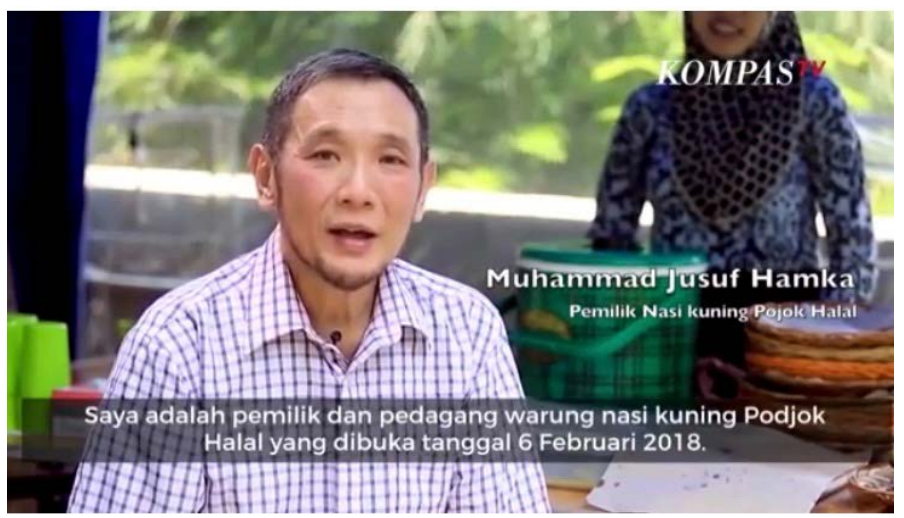

Figure 4. Kompas TV coverage of Jusuf Hamka.
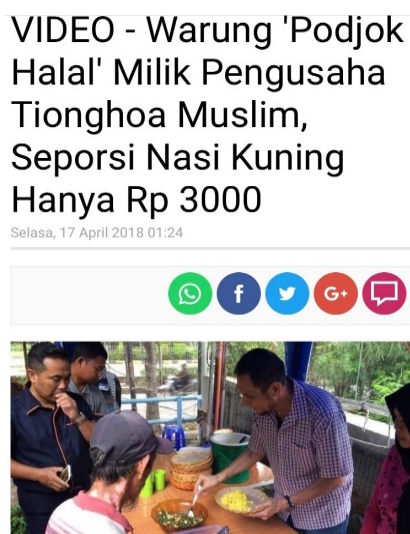

(Translated Headline News: "Podjok Halal" Food Stall Owned by a Chinese Moslem Businessman, a Serving of Yellow Rice Only Costs 3000 Rupiah)

Figure 5. Online news (TribunNews) coverage of Jusuf Hamka. 
regime (2004-present). Most of the first and second generations of ethnic Chinese experienced different identity association in relation to political situation and cultural politics they were going through. Their identity were unstable, wherein they had to cope with racial prejudice and forced assimilation policy during Suharto era, that led them to hide their Chinese identity completely. The fall of Suharto became the turning point for Indonesia's government, in which any anti-Chinese policies were removed and the New Order's assimilation policy was abolished. The revival of Chinese language, organizations, and media has gradually activated those Chinese Indonesians' emotional ties to their ancestral homeland. From the democratic transition era (Habibie-Abdurrahman Wahid-Megawati) up till the era of democratization (SBY and Jokowi), their cultural identity has gradually become more solid, prior to the celebration of Chinese cultural freedom.

Different from the first and second generations of Chinese Indonesians, the third and fourth generations of them who were mostly born between 1980s until 1990s, did not have a significant memories regarding the anti-Chinese sentiments those earlier generations have gone through. The majority of those subsequent generations had spent their adulthood in the post-Suharto era, therefore their Chinese identity was somehow protected and saved to some extent. However, for those younger generations who have more liberal political perspectives, the case of Ahok has once provoked either conflict of identity or cultural conflict between pribumi and ethnic Chinese, but at the end they could cope with the situation by respecting the mainstream culture, yet protecting their ethnic Culture. On the other hand, those earlier generations who have experienced the more harsh political circumstances during Suharto era, thought that Ahok has spoiled the good image of Chinese Indonesians who have been hardly built by the earlier generations of them. For them, based on their statements, it requires great effort to re-gain the trust from pribumi. Below are the participants' opinions in regard with Ahok's case based on their answers on the screening questionnaire in Table 2.

Almost half of the third and fourth generations of Chinese Indonesians (42\%) did not agree with the Ahok's imprisonment. In addition, $81 \%$ of the participants regarded the cultural integration as the best solution, compared to cultural

Table 2. Participants' standpoints.

\begin{tabular}{|c|c|c|c|c|c|}
\hline \multirow[b]{2}{*}{ No } & \multirow[b]{2}{*}{ Participants' Opinions } & \multicolumn{4}{|c|}{ Response } \\
\hline & & Agree & $\begin{array}{l}\text { Not } \\
\text { Agree }\end{array}$ & $\begin{array}{l}\text { Somewhere } \\
\text { in the middle }\end{array}$ & $\begin{array}{c}\text { No } \\
\text { Answer }\end{array}$ \\
\hline 1 & Two Years' Imprisonment of Ahok & $43 \%$ & $42 \%$ & $5 \%$ & $10 \%$ \\
\hline 2 & $\begin{array}{l}\text { Solution for Post Ahok's Imprisonment: } \\
\text { Cultural Assimilation }\end{array}$ & $13 \%$ & $72 \%$ & $7 \%$ & $8 \%$ \\
\hline 3 & $\begin{array}{l}\text { Solution for Post Ahok's Imprisonment: } \\
\text { Cultural Integration }\end{array}$ & $81 \%$ & $9 \%$ & $3 \%$ & $7 \%$ \\
\hline
\end{tabular}


assimilation. When being confirmed through the in-depth interview, most of the participants were aware of Ahok's shortcomings, but it was nor fair enough to imprison him, for he had conveyed his apology for the misconduct.

Furthermore, as ethnic Chinese, they preferred to preserve their ethnic culture, rather than assimilate with the mainstream culture. Their attitudes are somewhat contradictory to most of their response after being interviewed, wherein the majority of them were reluctant to express their Chinese-ness. Their resistance demonstrates that Ahok's case is responsible for constructing the generalised perception that regards the ethnic Chinese as unethical. As Philogene's [26] research into representations of black Americans and Africans has vividly illustrated, "when new circumstances force us, as a group or community, to rethink the present and imagine the future as part of adjusting to a changing reality", we develop to new or "anticipatory representations".

In contrast, the two earlier generations of ethnic Chinese participants agreed with the imprisonment of Ahok for blasphemy. In addition, cultural assimilation for them is indeed the best way to achieve unity in multi-ethnic country like Indonesia. However, through the participant observation, it can be observed that Jusuf has cooperated with Mainland China in regard with his business, where he imported a number of products from China (see Figure 6).

As an influential and popular figure, Jusuf is carefully trying to bring Chinese culture into contact with society who upholds the mainstream culture, therefore ethnic Chinese and pribumi will be able to coexist harmoniously. Different from Jusuf, Tamin frequently mentioned the cultural principle of Confucius filial piety during the interview so as to save the image of ethnic Chinese after Ahok's imprisonment. In short, those earlier generations and those younger generations of ethnic Chinese in Indonesia have the same standpoints, in which they are trying to protect their Chinese-ness without explicitly stating their cultural identity. The current situation forces both of those generations to cover their ethnic identity with their statement of resistance, but in certain cases, they implicitly

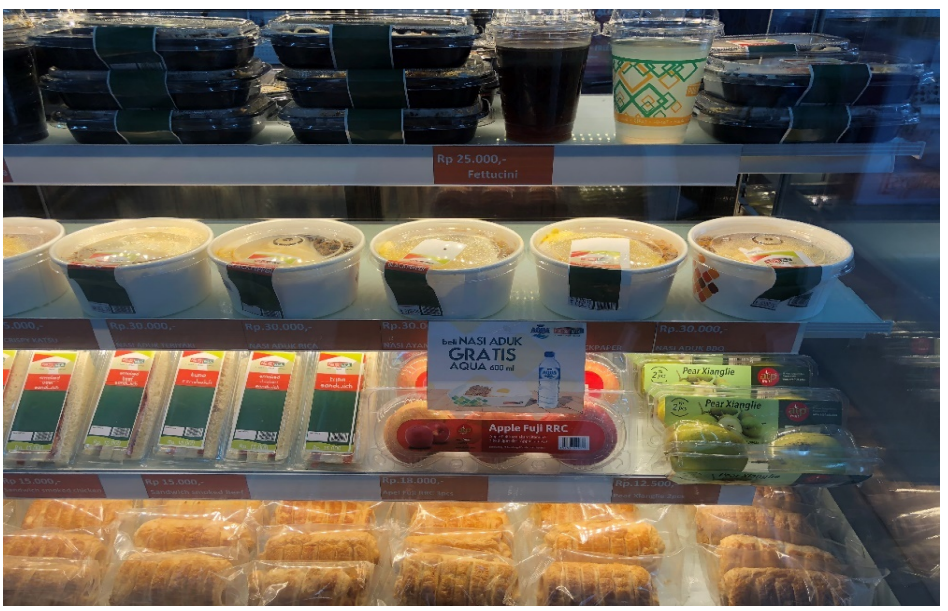

Source: Author's capture.

Figure 6. Food products imported by Jusuf Hamka. 
show their identity pride, without directly say it. The participants' contradictory attitudes reflect that their identities are not yet stable enough after Ahok's imprisonment. They, once again, fear of being marginalized and being like an underdog.

\subsection{False Self Image-Identity Dilemma}

Based on the screening questionnaires, most of the younger generations of Chinese Indonesians stated that they were still watching a number of Chinese films and TV drama series through Chinese online video platforms; Youku and PPTV. Both Youku and PPTV are popular Chinese video streaming website. However, a few other participants mentioned CCTV-4 as a television channel they mostly preferred so as to watch any Chinese movies. In this case, those participants preferred consuming any Chinese cultural products through Chinese media, rather than watching any Chinese cultural products through the local or other media. Through their preference, they manifested their sentiments of being Chinese. This is one of any other contradictory attitudes of those younger generations of Chinese Indonesians.

There are other supporting data gathered from newspapers that support the previous argument that Chinese Indonesians from any generations, actually have strong emotional ties to their ancestral homeland, and they still regard their ancestors' native place as their own place of origin. They would not assert their ethnic identity, but implicitly retain their Chinese-ness through their statements and any activities that put in a touch of Chinese culture that would stimulate their awareness that ethnic Chinese are parts of Indonesia. However, the post-Ahok's imprisonment has inevitably caused a racial tension between pribumi and ethnic Chinese.

In April 2017, a younger generation of ethnic Chinese, Steven Hadisuryo Sulistyo, scolded the current Governor of West Nusa Tenggara, M. Zainul Majdi, harshly. The incident occurred in Changi International Airport, Singapore, where Steven accused Governor Zainul of cutting the line while queeing. Steven racially insulted Governor Zainul by calling him "pribumi". Even though the misunderstanding between Steven and Governor Zainul had been resolved, wherein Steven conveyed his apology for accusing and insulting Governor Zainul of the act he did not do at all, the case had gone viral and most native Indonesians condemned Steven as an uncivilized Chinese Indonesian. This has provoked another racial tension after Ahok's imprisonment and caused the majority of Chinese Indonesians under pressure.

Another case is when Sukanto Tanoto, a Chinese Indonesian businessman who involved primarily in the lumber industry, stated that he recognized Indonesia as his stepfather during his visit in China. For him, Mainland China is his real father, where his heart resides, even though he was born and raised in Indonesia (see Figure 7). His statement has been covered by a number of online newspapers and reached a large number of people. Indonesians, once again, 


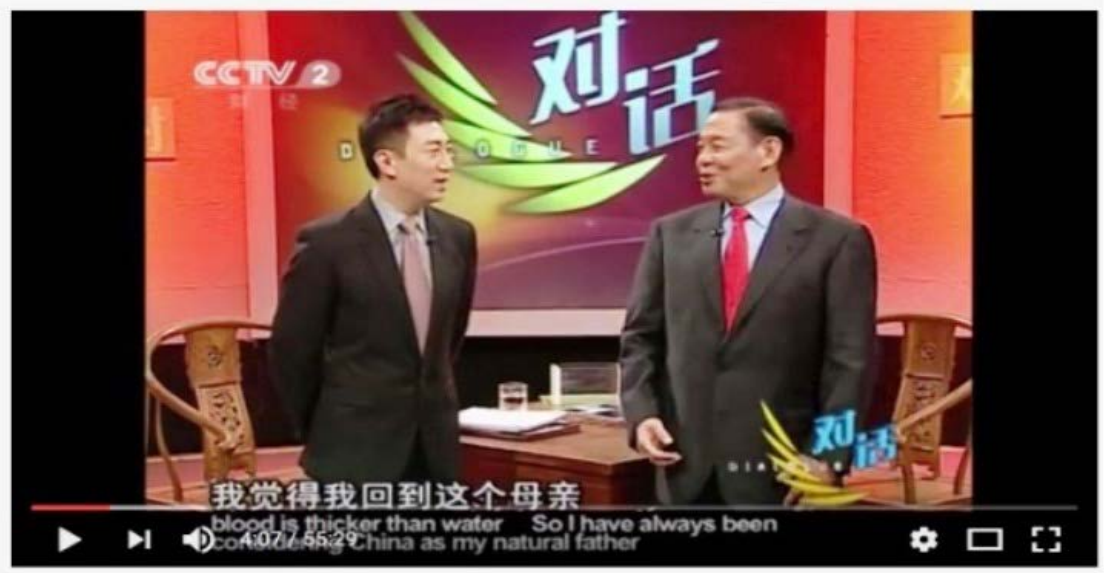

RGE Chairman Sukanto Tanoto shares his story

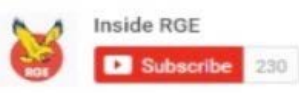

10,681 views

Figure 7. Sukanto Tanoto's statement broadcasted by CCTV 2.

were offended and considered him as being disloyal to his birthplace. In this sense, both Steven, as a younger generation of Chinese Indonesians, and Sukanto, the earlier generation of ethnic Chinese, represent their attachment to their ancestral homeland which has been instilled into them, regardless of the fact both of them were born in Indonesia.

During the interview with Jusuf and Tamin, they stated they were disappointed with both Steven and Sukanto misbehaviour. They once again emphasized that Steven and Sukanto's actions of misbehaving do not represent ethnic Chinese attitude in general. They are just a few of Chinese Indonesians who are disloyal to their land of birth. Nevertheless, both Jusuf and Tamin are somehow trying to improve the image of their ethnicity through their statements and cultural activities. Through their contributions to the society, Indonesians, where they carefully bring Chinese culture into contact with pribumi, their attachment to Mainland China is clearly seen. As Byrna Goodman shows, loving the native place was a sign of loving the nation. Ties to native places on Chinese soil invoked and connected meanings of Chinese-ness as a territorial, racial, cultural, and national identity [27]. Louie added that to native place were inherited, so that even immigrants to other parts of China would still claim their grandfather's native place as their own place of origin, even if they have never been there. This situation is what actually occurs in Indonesia, where Chinese Indonesians' sentiment for their homeland is very strong, yet deep, private, and individual. They prevent demonstrating their homeland-sentiments, for they fear being the target of pribumis anger accusing them of being disloyal.

In the three and a half years of Jokowi-Kalla administration, the country has experienced some improvements in multiple sectors. However, the last one and a half year has been rather tough, for a number of racial cases occurred after Ahok has provoked anger of the majority of Moslems, that led him to two years 
jail for blasphemy. Issues of inequality and ethnic minority being marginalized had been headline news in a number of popular online newspapers. The racial cases have gone viral and Chinese Indonesians, particularly those younger generations, once again were under pressure. Therefore, protecting and saving their ethnic identity, yet resisted being identified as "Chinese" in public, indicate that they experience identity dilemma. They tend to create false self image, in which they stated 'their home is Indonesia', so as to avoid being regarded as being unfaithful to their land of birth.

\subsection{New Type of Cultural Long-Distance Nationalism}

The bilateral relationship between China and Indonesians has blossomed over the last fifteen years, particularly in the reign of Jokowi-Kalla, as the incumbent President and vice President with a commitment to protect religious and ethnic minorities in Indonesia, even though Ahok as the former popular ethnic Chinese governor of Jakarta was sent to jail due to a criminal act of blasphemy. In spite of the fact that a racial tension occurred during the second year of Jokowi-Kalla administration, cultural long-distance nationalism of Chinese Indonesians can be observed, even though it was not explicitly stated.

The first and foremost is the enhanced cooperation between Indonesia and Mainland China in many strategic sectors. Chinese Indonesians play significant roles in bridging the gap between the two countries. As mentioned before, there are a number of influential figures of Chinese Descent who have been appointed by Jokowi in his working cabinet; Ignasius Jonan, Minister of Energy and Mineral Resources, and Thomas Lembong, Chairman of Indonesia Investment Coordinating Board. In May 2018, Chinese Premier Li Keqiang visited Indonesia and met the vice President of Indonesia, Jusuf Kalla, to discuss the bilateral partnership between the two countries. As China and Indonesia are both developing economies and populous countries with a huge market potential, both sides vowed to strengthen bilateral ties and economic cooperation. The Indonesian side is ready to further strengthen exchanges and cooperation in the areas of economy, trade, culture, education, and maritime development, so as to push bilateral relations to a new level.

Through the Indonesia-China cooperation in culture and education, Chinese government will be able to expand its political and social values to ethnic Chinese in Indonesia. As China showcases its rise as a great power to the world, a sense of belonging to their ancestral nation will be unconsciously evolved. Xiaoling [28] argued that China has been making big investment in its "go global" (also called "go-out") project, including launching multi-language satellite TV channels and websites, staging heritage exhibitions and art and cultural performances overseas, sponsoring overseas students to study in China and paying for Chinese-language programmes abroad. There have been seven Confucius Institutes established in Indonesia, as stated by Ju Lan [29], which play an important role in gathering and establishing a group of local people who welcome and 
support China's friendly attitude. The establishment is unquestionably aimed at enhancing the understanding and friendship between the two people and strengthen the education and cultural exchanges and cooperation between two sides. It has been said that the Confucius Institute at Al Azhar University in Jakarta was built with philanthropic donations from a number of Chinese Indonesians. One of the philanthropers stated that the motive of the establishment of Confucius Institute at $\mathrm{Al}$ Azhar University Jakarta is not only philanthropic, but also political. It is hoped that indigenous Indonesians will learn much about China through programs provided by Confucius Institutes, so as to make them less prejudice towards Chinese.

In terms of cultural exchange, today the development on Chinese language studies in several Indonesian universities can be observed. In addition, there is a growing interest in studying China and Chinese language in Indonesia and in pursuing further study in China. Ju Lan [29] stated that in 2014, UIN (Universitas Islam Negeri, Muslim State University) Ar-Raniry, in Aceh, in cooperation with Wuhan University of Technology (with an agreement signed on April $15^{\text {th }}$ 2014), sent seven of its female students to study in Master's Programme in China. In 2018 there are almost fifteen thousand students studying in Indonesia [30]. Since there are a large number of students studying in China, those students who have learnt Chinese culture will help bridging the gap and misunderstanding between Indonesia and Mainland China, and pribumi and Chinese. Figure 8 below is the increased number of Indonesian students studying in China:

The majority of participants even mentioned CCTV-4 and Celestial Movies as their favourite Chinese Cable TV channels to watch some Chinese entertainment programs. The portrait of China and its cultural values will surely be illustrated through any cultural products broadcasted by TV channels. Therefore, the viewers who are mostly Chinese Indonesians will be able to associate their Chinese

\section{Number of Indonesians Students studying in China}

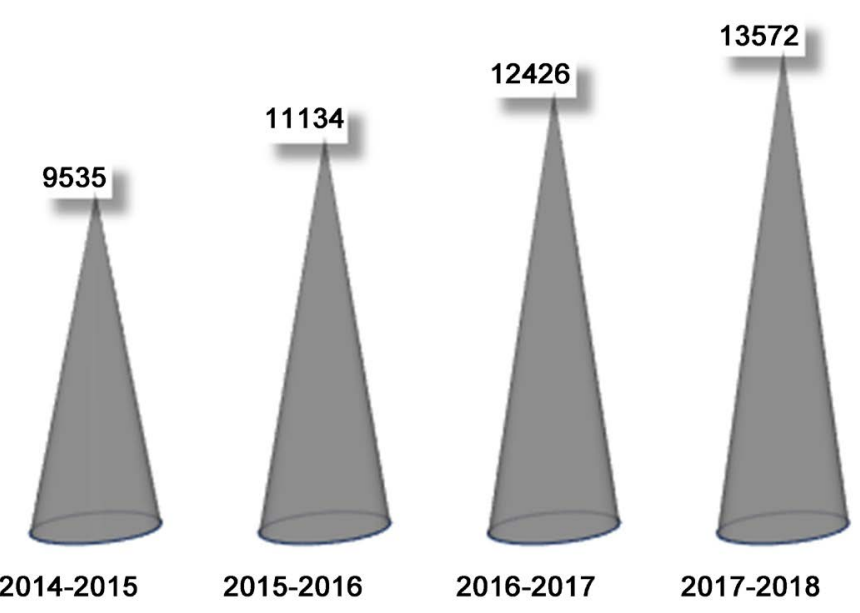

Source: Indonesian Students Association in China, 2018.

Figure 8. Number of Indonesians students studying in China. 
identity accordingly. Xiaoling [29] stated that China considers its media an important part of its effort to go global. It has therefore expanded its communication channels rapidly, wherein the media will somehow contribute to the identity formation of overseas Chinese. In this sense, culture is considered the main source of attraction so as to provoke the emotional attachment of ethnic Chinese to their ancestral homeland. As stated by Joseph Nye [25], the concept of soft power puts a strong emphasis on "the power of attraction" as tool to persuade or "to shape the preferences of others".

What actually happened during Jokowi-Kalla administration, particularly after the imprisonment of Ahok, is actually a new type of cultural long distance nationalism. In this case, the majority of Chinese Indonesians, as observed from screening questionnaires, in-depth interview, and participant observation, experience racial tension, therefore they are inclined to protect and save the image of Chinese cultural identity in public, through self-effacement, philanthropic activities to promote Chinese cultural values, involvement of Chinese elements in social activities, and the enhancement of Indonesia-China bilateral partnership, especially in education and culture. Those soft approaches implemented by Chinese Indonesians as the mediator between Indonesia and Mainland China. Therefore, the cultural long-distance nationalism in Indonesia is not expressively asserted, but it is indirectly shown through the soft approaches taken by the majority of Chinese Indonesians during the latest one and a half year of Jokowi-Kalla administration.

\section{Conclusions}

Chinese Indonesians has experienced a positive state of mind and self-confident in the first two years of Jokowi administration, and self-effacement in the last one and a half year of Jokowi era, due to Ahok's two-year imprisonment. This identity dilemma has caused by undesirable event (sociocultural context) and representation of cultural trauma. However, due to the democratic perspective of Jokowi, Chinese Indonesians still have their way to maintain their ethnic identity, through the use of new media and support from Chinese communities. The cultural long-distance nationalism can be observed through their effort to improve the image of Chinese identity and the cultural activities held in order to emphasize the existence of ethnic Chinese in Indonesia. However, further research using the quantitative method is considered important so as to justify the strong emotional attachment of those third-and-fourth generations of Chinese Indonesians during Jokowi era.

In addition, this study has shown that most Chinese Indonesians, as ethnic minority, today are still facing identity dilemma, in spite of the fact that they are now living under the rule of democratic government. Ahok's case has become a test of Indonesia's commitment to pluralism and a reflection of the failure of commitment to the values of multiculturalism. Ethnic Chinese in Indonesia came in contact with different cultural, political, and social conditions, com- 
pared with other ethnic Chinese living in other parts of the world. Therefore, the research supports Phinney's statement that identity depends on time and context.

\section{References}

[1] Minghua, X. and Ingketria, E. (2016) Chinese Indonesians at the Crossroads: Post-Suharto Identity Dilemma in the Rise of China in the New Era. Proceeding of Asian Conference on Culture Studies, Kobe, 2-5 June 2016, 225-237.

[2] Sen, K. (2006) Chinese Indonesians in National Cinema 1. Inter-Asia Cultural Studies, 7, 171-184. https://doi.org/10.1080/14649370500463877

[3] Setijadi, C. (2013) Chineseness, Belonging, and Cosmopolitan Subjectivities in Post-Suharto Independent Films. In: Hoon, C.-Y. and Sai, S.M., Eds., Chinese Indonesians Reassessed: History, Religion and Belonging, Routledge, London, 25-36.

[4] Suryadinata, L. (2008) Chinese Indonesians in an Era of Globalization: Some Major Characteristics. In: Suryadinata, L., Ed., Ethnic Chinese in Contemporary Indonesia, ISEAS Publications, Singapore, 1-16. https://doi.org/10.1355/9789812308368-005

[5] Tickell, P. (2009) Indonesian Identity after the Dictatorship: Imagining Chineseness in Recent Literature and Film. In: Sakai, M., Banks, G. and Walker, J.H., Eds., The Politics of the Periphery in Indonesia: Social and Geographical Perspectives, National University of Singapore Press, Singapore, 274-295.

[6] Phinney, J.S. (1996) Understanding Ethnic Diversity: The Role of Ethnic Identity. American Behavioral Scientist, 40, 143-152.

https://doi.org/10.1177/0002764296040002005

[7] Elections in Indonesia-2014 National Legislative Elections (2014) International Foundations for Electoral Systems.

http://www.ifes.org/sites/default/files/indonesia_2014_national_legislative_election faq.pdf

[8] Bland, B. (2014) Widodo's Party Set to Win Indonesia Parliamentary Election. Financial Times. https://www.ft.com/content/3e789f00-bfaa-11e3-b6e8-00144feabdc0

[9] Emont, J. (2014) Jokowi, the "Indonesian Obama," Is in a Presidential Nail-Biter. The New Republic.

https://newrepublic.com/article/118613/indonesia-election-results-2014-joko-jokow i-widodo-nail-biter

[10] Dewi, S.W. and Ayuningtyas, K. (2013) Elite Engineering Gives Birth to Jokowi's Ascension. The Jakarta Post.

http://www.thejakartapost.com/news/2013/11/19/elite-engineering-give-birth-joko wi-s-ascension.html

[11] Ali-Fauzi, I. and Hillman, B. (2015) Confronting Intolerance: New Hope for Indonesia's Religious Minorities. PUSAD.

http://www.paramadina-pusad.or.id/publikasi/kolom/confronting-intolerance-newhope-for-indonesias-religious-minorities.html

[12] Emont, J. (2016) Visionary or Cautious Reformer? Indonesian President Joko Widodo's Two Years in Office. TIME.

http://time.com/4416354/indonesia-joko-jokowi-widodo-terrorism-lgbt-economy/

[13] Panjaitan, R. (2016) President Jokowi Leads Indonesia Out of Its Comfort Zone. Globe Asia.

http://www.globeasia.com/special-reports/president-jokowi-leads-indonesia-out-of- 
its-comfort-zone

[14] Chen, Q. (2017) Indonesian President Jokowi: A Reform-Minded Leader. Global Risk Insights.

https:/globalriskinsights.com/2017/01/president-jokowi-reform-minded-leader/

[15] Parwitasari, W. (2017) Indonesia, China Sign Agreement on Energy. The Jakarta Post.

http://www.thejakartapost.com/news/2017/11/13/indonesia-china-sign-agreementon-energy.html

[16] Parameswaran, P. (2015) China and Indonesia under Jokowi: Show Me the Money. The Diplomat.

https://thediplomat.com/2015/01/china-and-indonesia-under-jokowi-show-me-the -money

[17] Nambiar, S. (2016) Will Indonesia Succumb to China? Forbes. https://www.forbes.com/sites/realspin/2016/10/19/will-indonesia-succumb-to-china/

[18] Setijadi, C. (2015) Ethnic Chinese in Contemporary Indonesia: Changing Identity Politics and the Paradox of Signification. ISEAS-Yusof Ishak Institute.

[19] Nugroho, J. (2016) Stormy with a Chance of Ahok. Jakarta Globe. http://www.jakartaglobe.beritasatu.com/columns/johannes-nugroho-stormy-chance -ahok/

[20] Tanaya, K.M. (2017) The Apotheosis of Ahok. Woroni. https://www.woroni.com.au/words/the-apotheosis-of-ahok/

[21] Lamb, K. (2016) Jakarta Governor Ahok's Blasphemy Trial: All You Need to Know. https://amp.theguardian.com/world/2016/dec/12/jakarta-governor-ahoks-blasphem y-trial-all-you-need-to-know

[22] Chung-Yan, C. (2017) The Plight of Chinese Indonesians: Distrusted in Jakarta, Forgotten in China.

http://www.scmp.com/week-asia/opinion/article/2073851/plight-chinese-indonesia ns-distrusted-jakarta-forgotten-china

[23] Rakhmat, M.Z. (2017) The Dark Side of Indonesia's Social Media Boom. The Diplomat.

https://thediplomat.com/2017/05/the-dark-side-of-indonesias-social-media-boom/

[24] Lukman, E. (2015) The Latest Numbers on Web, Mobile, and Social Media in Indonesia. Tech in Asia.

https://www.techinasia.com/indonesia-web-mobile-data-start-2015

[25] Nye Jr., J.S. (2008) Public Diplomacy and Soft Power. The Annuals of the American Academy of Political and Social Science, 616, 94-109. https://doi.org/10.1177/0002716207311699

[26] Philogene, G. (2001) From Race to Culture: The Emergence of American. In: Deaux, K. and Philogene, G., Eds., Social Representations. Introductions and EXplorations. Blackwell, Oxford.

[27] Goodman, B. (1995) Native Place, City, and Nation: Regional Networks and Identities in Shanghai, 1853-1937. University of California Press, Berkeley.

[28] Zhang, X. (2010) Chinese State Media Going Global. East Asia Policy, 2, 42-50.

[29] Lan, T.J. (2017) Confucius Institute at Universitas Al Azhar, Jakarta: The Unseen Power of China. Wacana, 18, 148-182. https://doi.org/10.17510/wacana.v18i1.576

[30] Wahyono, E. (2018) Mengapa Harus Belajar ke China. DetikX. https://x.detik.com/detail/intermeso/20180507/Mengapa-Harus-Belajar-ke-China/i ndex.php 


\section{Appendix A: Screening Questionnaire}

You have been asked to complete this survey as part of your participation in this study. I will keep completed surveys securely in my care, and I will keep all personal information strictly confidential. I will destroy all surveys at the end of the study.

If you could take the time to complete the survey, it would be greatly appreciated. I hope that you will answer all the questions. However, if you come to a question that you do not wish to answer, please skip it and proceed to the next question.

Participation in this study is voluntary. You may refuse to participate or withdraw at any time without penalty. Although you may receive no direct benefits from participation, this study may help you better understand your identity as a Chinese in Indonesia.

\section{Informational Survey}

1) Name:

2) Sex (please circle):

Female $\quad$ Male

3) Place and Date of Birth:

4) Occupation:

5) Telephone number and/or email address:

Telephone number: Email:

6) Highest level of education achieved (please circle):

Elementary School Secondary School High School

Bachelor's Master's Doctorate

7) Have you lived outside of Indonesia? YES/NO (please circle)

If you answered YES, please indicate where and how long you stayed in that country.

8) How long has your family lived in Indonesia?

9) Where did your ancestors originate from? When did they arrive in Indonesia?

10) Do you consider yourself proficient in Mandarin or other Chinese dialects (Hokkien, Hakka/Khe, Hokchia, Teochew, .....)? 
YES/NO (please circle)

If you answered YES, please go to question 11.

If you answered NO, please go to question 12 .

11) How would you rate your proficiency in Mandarin/other Chinese dialects?

Please circle the most appropriate answer:
(a) Reading: Poor
Fair
Good
Excellent
(b) Writing: Poor
Fair
Good
Excellent
(c) Speaking:
Poor
Fair
Good
Excellent

12) Do you wish that you were proficient in Mandarin/other Chinese dialects? Why or why not?

13) Did you watch Chinese films/serials when you were growing up?

YES/NO (please circle)

If you answered YES, please list three titles of films/serials that you watched while growing up:
a.
b.
c.

14) Do you watch Chinese films/serials now? YES/NO (please circle)

If you answered YES, please list three titles of films/serials that you are watching now:

a.

b.

c.

15) What Media are you using to watch Chinese films/serials? Mass Media (television) or New Media (Online Platforms)? Please mention.

16) Are using Social Media (e.g. Facebook, Instagram, Twitter, Path, etc.)? Do you think Social Media have important roles in obtaining more information about Chinese culture? 


\section{If you are born between 1990 and 1998, kindly answer the following} questions.

17) Do you have idols who are Chinese Indonesians? Please explain why do you adore them?

18) What do you think about Ahok, the former Governor of Jakarta, performance? Please explain.

19) How do you feel about Ahok's two-year imprisonment? Did he deserve that?

Kindly choose your response below:

\begin{tabular}{|c|c|c|c|c|c|}
\hline \multirow[b]{2}{*}{ No } & & \multicolumn{4}{|c|}{ Response } \\
\hline & & Agree & $\begin{array}{c}\text { Not } \\
\text { Agree }\end{array}$ & $\begin{array}{l}\text { Somewhere in } \\
\text { the middle }\end{array}$ & $\begin{array}{c}\text { No } \\
\text { Answer }\end{array}$ \\
\hline 1 & Two Years' Imprisonment of Ahok & & & & \\
\hline 2 & $\begin{array}{l}\text { Solution for Post Ahok's Imprisonment: } \\
\text { Cultural Assimilation }\end{array}$ & & & & \\
\hline 3 & $\begin{array}{l}\text { Solution for Post Ahok's Imprisonment: } \\
\text { Cultural Integration }\end{array}$ & & & & \\
\hline
\end{tabular}

Note: ${ }^{*}$ Cultural assimilation: The process in which Chinese culture comes to resemble those of the pribumi. ${ }^{*}$ Cultural integration: Co-existence between Chinese culture and pribumis.

\section{Appendix B: Questions for In-Depth Interview}

1) As an earlier generation of ethnic Chinese in Indonesia, how do you feel about being an ethnic minority in Indonesia?

2) How did you learn Chinese values?

3) What do you think about cultural assimilation enforced by Suharto?

4) Did you feel the difference living under the rule of Suharto and Post-Suharto leaders?

5) Whom do you think the best Post-Suharto Presidents who led Indonesia into a democratic phase?

6) What do you think about our incumbent President, Joko Widodo? How about his image as being pluralist?

7) How do you feel about Ahok conviction for blasphemy?

8) How do you solve the racial tension created after the imprisonment of Ahok as the former Governor of Jakarta?

9) What do you think about the future of Chinese Indonesians?

10) What are the best solutions for democratic society in Indonesia? And your suggestions for inter-ethnic harmony in multicultural societies? 